\title{
Kazakhstan and Central Asia: Regional perspectives
}

\section{Zharmukhamed Zardykhan}

To cite this article: Zharmukhamed Zardykhan (2002) Kazakhstan and Central Asia: Regional perspectives, Central Asian Survey, 21:2, 167-183, DOI: 10.1080/0263493022000010062

To link to this article: http://dx.doi.org/10.1080/0263493022000010062

$$
\text { 曲 Published online: } 01 \text { Jul } 2010 .
$$

Submit your article to this journal $\pi$

LIII Article views: 340

Q View related articles $\sqsubset$

4 Citing articles: 1 View citing articles 준 


\title{
Kazakhstan and Central Asia: regional perspectives
}

\author{
ZHARMUKHAMED ZARDYKHAN
}

Throughout the Soviet period, Kazakhstan has been regarded as a geographical and historical extension of Southern Siberia. While the rest of Central Asia was named Srednyaya aziya (Middle Asia), the term Srednyaya aziya i Kazakhstan (Middle Asia and Kazakhstan) became used to denote the whole of Soviet Central Asia. Historically, the area that is now Kazakhstan fell under the tsarist rule about a century earlier than so-called Middle Asia and started to be integrated into the imperial economy and administration. The Kazakh Khanate was established by Janibek and Geray Khans, two sons of Barak Khan, in the second half of the 15th century and encompassed the seceded tribes and families that formerly belonged to the state of Nomadic Uzbeks under Abulkhayr Khan (the grandfather of Shaybani Khan, the founder of the Shaybanide state), when the state of Abulkhayr was severely weakened by the invasion of the Jungars.

From the mid-15th century until the beginning of the 17th century, the Kazakh Khanate was a unified political entity. In the 17 th century the khanate broke up and was divided into several separate khanates. According to Muhammed Haydar Dughlat, the Kazakh Khanate was founded in Hijra 870 (1465-1466), and the number of Kazakhs under the rule of Janibek and Geray reached 200,000 in $1468 .{ }^{1}$ From its establishment until its elimination, the Kazakh Khanate was a rival to the Khiva and Khokand khanates, remnants of the Uzbek state, waging several wars against them that resulted in many territories being passed from one side to another.

The Central Asian republics have many things in common: common history and ties, common problems of independent state building, and a perceived common threat from Russia, China and extremist religious groups. At the beginning of their 'independent career' they operated harmoniously within the CIS by co-ordinating their actions. With the consolidation of their state independence and the all-powerful local leaderships, however, the harmony among the Central Asian republics turned into harsh rivalries, although their official rhetoric of 'eternal brotherhood' was not lost. The Central Asian republics may still use any possibility to hamper the other Central Asian states' promotion, but there are certain vulnerabilities that still force them to co-operate: their political oppo- 
sition (it is impossible to hear any criticism about the lack of democracy from any leader of these states about the other), radical Islam, drug trafficking and, of course, the Russian threat - though the priorities for every state are different. All these states are still dependent on Russia, either politically or economically or both, and they are in severe competition for Russian and Western aid and investment.

\section{Kazak-Uzbek relations and struggle for Central Asian leadership}

Among the five Central Asian states, Uzbekistan and Kazakhstan are the most influential ones with regard to their populations, economic and military power, demographic compound, and geography. The population of each of the two states is greater than that of the rest of Central Asia. By July 1995, Kazakhstan and Uzbekistan had populations of 17.4 and 23.1 million respectively; their GDP amounted to 55.2 and 54.5 billion dollars, and their armed forces had 40,000 and 25,000 men. $^{2}$ Another feature that made Uzbekistan very influential in the region was its demographic structure: it has a relatively homogeneous population where Uzbeks represent more than 75 per cent $^{3}$ of the whole population, as well as considerable Uzbek minorities in all other Central Asian republics. Under these circumstances, the two countries compete for leadership in the region, where Kazakhstan initiated regional co-operation and integration as a means to counterbalance its vulnerability vis-à-vis Russia. Kyrgyzstan, with its large Uzbek minority and several zones of dispute, tried to counterbalance the Uzbek threat under an umbrella comprising the whole region. Turkmenistan, with its small population and rich natural resources, tried to avoid any kind of integration in order not to fall under Uzbek or Kazakh influence. The 'struggle' between these two countries was also apparent between the two leaders, presidents Nazarbayev and Karimov: whereas the former became the innovator of any ideas of co-operation, the latter consistently rejected them. ${ }^{4}$ For the most part, Kazakhstan's initiatives to create a 'Central Asian Union' were a response to Russian endeavours in Belarus and Ukraine. In addition, Kazakhstan's co-operation with the Central Asian states had been its first experience of 'external' co-operation without Russian supervision.

The first meeting of the Central Asian leaders took place in Almaty on 23 June 1990, when then the First Secretary of the Kazakh Communist Party, Nursultan Nazarbayev, invited the Communist leaders of the Central Asian republics: Niyazov of Turkmenistan, Makhkamov of Tajikistan, Karimov of Uzbekistan and Masaliyev of Kyrgyzstan. ${ }^{5}$ Following the collapse of the USSR, the newly independent regional states increased co-operation attempts, such as in December 1991 in a response to the Slavic Union. At a June 1990 summit, regional councils met to solve common problems of cultural, scientific and environmental matters, which formed the first serious stage of institutionalizing regional co-operation. Another meeting of the Central Asian leaders was held in Ashkabad, on 12 December 1991. ${ }^{6}$ The participation of Azerbaijan gave the meeting 
a Turkic-Muslim atmosphere, but the ongoing war with Armenia hampered the latter's co-operation with Central Asia.

One of the most important meetings among the regional powers was held in early January 1993 in Tashkent, where the term Tsentral'naya aziya (Central Asia) was formally adopted to designate the Central Asian states including Kazakhstan, instead of Srednyaya aziya $i$ Kazakhstan (Middle Asia and Kazakhstan). ${ }^{7}$ One of the most important conclusions of the meeting was the creation of a common market and a plan to co-ordinate economic policies. ${ }^{8}$ The next stage of regional co-operation was launched mainly by Kazakhstan and Uzbekistan with Kyrgyzstan's indispensable participation in every project. Turkmenistan followed its policy of 'neutralism' and Tajikistan ran into a civil war with Russia's instigation and support. In January 1994, the presidents of Kazakhstan and Uzbekistan signed bilateral agreements on the creation of a common market, the abolishment of customs checkpoints, and free border crossing for their citizens. ${ }^{9}$ Later that year Kyrgyzstan also joined the 'KazakhUzbek Union' and the trilateral agreement was signed on 30 April 1994. ${ }^{10}$ During the Almaty summit held on 8 June 1994, the three countries established an Interstate Council, an Executive Committee and founded the Council of Prime Ministers, the Council of Foreign Ministers and the Council of Defence Ministers. ${ }^{11}$ On 8 July 1994, the participants established the Central Asian Bank for Co-operation and Development facilitating interstate fiscal transactions, but in reality, most of these gestures of ardent friendship and co-operation simply remained on paper and the two republics followed independent paths: Uzbekistan was more concerned with its domestic 'Islamist' opposition and actively 'participated' in the Tajik-Afghan crisis, while Kazakhstan continued its 'integrationist' policy and nation-building process. Not surprisingly, Uzbekistan and Turkmenistan did not participate in Nazarbayev's conference on Eurasian Union organized in Almaty. ${ }^{12}$ Also, the Uzbek side hesitated with regard to the idea of Central Asian trilateral integration after the marriage of Nazarbayev's youngest daughter and Akayev's son.

\section{Long-lasting tradition: the border issue}

One of the most vulnerable issues between the Central Asian states is that of their borders. This issue can be considered a legacy of the Soviet period, which created them artificially with no regard to prevalent ethnic, geographical, or economic conditions. In addition to these borders, some purely artificial ethnicities had been created, such as the Karakalpaks, whose titular land was initially a part of the Kazakh ASSR. It later was transferred to the RSFSR, and had finally been incorporated into Uzbekistan as the Karakalpak ASSR in 1936. The border disputes between Kazakhstan and Uzbekistan had been exacerbated by their status during Soviet times: the borders were simply the domestic administrative lines between the two Soviet republics and were prone to be changed, since none were demarcated nor delineated.

On 24 June 1992, the two countries signed the Treaty of Friendship, Co- 
operation, and Mutual Assistance. The treaty guarantees the principle of noninterference in each other's internal affairs and does 'recognize and respect territorial integrity and inviolability of existing borders between Kazakhstan and Uzbekistan, and denounce any kind of encroachment on these borders. Any establishment and change of the state border regime would be implemented on mutual agreement.' 13 The approximate length of the Kazakh-Uzbek border is $230 \mathrm{~km} .{ }^{14}$

For the last few years, a growing number of incidents occurred in the border zone and became more violent. The two countries started to increase the number of troops in this 'friendly zone'. Drug smuggling and illegal immigration also increased. In one month-January 2000 - several armed clashes occurred between the border guards of the two countries, sometimes involving local populations, especially in the disputed zone that comprises an area of more than 15,000 hectares. $^{15}$

On 25 January 2000, Uzbek border guards in their armoured personnel carrier penetrated the Kazakh territories for $50 \mathrm{~km}$ and started to mark out a line of $60 \mathrm{~km}$ long $^{16}$ (according to Nezavisimaya gazeta, they advanced $50 \mathrm{~km}$ and delineated a zone of about 22,000 hectares). ${ }^{17}$ The Kazakh government, in a diplomatic note sent to Tashkent, called the occasion an 'invasion of the territory of a sovereign state' ${ }^{18}$ and the Kazakh Foreign Minister Erlan Idrisov stated that Kazakhstan 'will not give up an inch of land'. ${ }^{19}$ The Kazakh side had started its troop positioning in September $1999 .{ }^{20}$ Until that time, it was an unguarded zone. Following the incident, both sides started negotiations on the demarcation of the border while both parties continued to increase the number of the border troops and facilities. Upon the note of protest from the Kazakh side, the Uzbek Foreign Minister Abdulaziz Kamilov stated that 'there are not and will not be any territorial tension between Uzbekistan and Kazakhstan. ... The subject of border disputes between Uzbekistan and Kazakhstan is being "artificially puffed up" these days, while the issue involves only delimitation and demarcation of the border between the two countries. ${ }^{21}$ The border incident that stirred up a diplomatic clash within a couple of days settled down through negotiation s by bilateral working groups, starting the process of demarcation. According to the Kazakh Foreign Minister, by June 2000, $40 \mathrm{~km}$ of borderline had already been demarcated. ${ }^{22}$ In July 2000, Kazakhstan started negotiations on the delimitation and demarcation of the state border with the Republic of Kyrgyzstan. ${ }^{23}$ Thus, Kazakhstan started to acquire one of the most important requirements of an independent state-real and recognized borders. Interestingly, the rightist Kazakh parties, such as Alash and Azat, which use any possible excuse to criticize and picket the Russian embassy in conflicts involving Russia, did not forward their protests to the Uzbek side after the border accident. ${ }^{24}$

\section{Kazakhstan and the Kazakhs in Uzbekistan}

Another specific feature that makes Kazakh-Uzbek relations tense and which prevents an adequate solution of the border problem is the issue of minorities: 
the Kazakh minority in Uzbekistan and the Uzbek minority in Kazakhstan. As a result of Soviet state-building practice, particularly, the creation of state nationalism, several parts of Kazakh territories passed to Uzbekistan, and reciprocally, some Uzbek territories passed to Kazakhstan. Ironically, some territories, such as the Makhta-Aral district, ${ }^{25}$ passed from one side to another several times.

According to the 1989 census, some 808,000 Kazakhs lived in Uzbekistan and some 332,000 Uzbeks in Kazakhstan; today these numbers are supposed to reach at least 1.2 million and 400,000 respectively, and because of the similar birth-rate among the two societies the ratio is not likely to change. ${ }^{26}$ There are also considerable Uzbek minorities in all other Central Asian countries: Kyrgyzstan, Tajikistan, and Turkmenistan. In this regard, Kazakhstan seems relatively free of Uzbek influence, while the Kazakh minority in Uzbekistan, on the contrary, seems to be more influential. After the collapse of the Soviet Union, a number of Uzbekistani Kazakhs migrated to Kazakhstan for permanent residence. The Kazakhs in Uzbekistan, the second largest Kazakh community abroad after that of China, are spread all over the country, but the largest number of them (more than 500,000) live in Central Uzbekistan (Tashkent Oblast, Tashkent City, Syr-Darya Oblast). ${ }^{27}$ A great number of Uzbeks in Kazakhstan live in the Chimkent region amounting to some 280,000 people. ${ }^{28}$

After obtaining independence, the two countries did not intend to involve these minorities in their foreign policy. Several trivial clashes between ethnic Kazakhs and Uzbeks had been controlled and calmed down by officials. Therefore, the claims of both sides-Uzbeks' aspirations to incorporate some regions of Southern Kazakhstan, the former territories of the Khokand Khanate, into Uzbekistan and Kazakhs' aspirations on Uzbekistan's present capital Tashkent, allegedly the lands of the Kazakh Ulu Jüz (Great Horde)—have not so far been taken up by the official organs of either country.

\section{Tajik-Afghan crisis and 'radical Islam'}

After the collapse of the Soviet Union, many of the newly independent states regarded Communism as an impending threat to the former Soviet territories. This attitude provided support for the republics' leadership, either from the West, from Russia or from other former Soviet states, during the period of transition when the republics were severely dependent on external aid. In this regard, Kazakhstan was not an exception. The Kazakh leadership was aware of the fact that without democratization, integration of the state's economy into the world economy, and elimination of an anti-Western orientation in foreign policy the country could not receive foreign aid that was an indispensable condition for the leadership's survival. However, towards the end of the 1990s the threat of Communism lost its former acuteness and the West became concerned with democratization and human rights, which became the prerequisite for economic aid. Thus, the task of preventing the spread of 'radical Islam', terrorism and extremism, building regional stability, the struggle against drug and arms 
smuggling became the mean to show the region's key role in the world's stability, to obtain foreign aid and to avoid becoming a legitimate cause for antidemocratic sanctions. In this regard, Afghanistan with its ongoing civil war, and Tajikistan, the unstable country in Central Asia, were presented as the cradle of an 'Islamic International' and the 'bow of Islamic extremism'. The problem of Islamic extremism, cradled somehow between Russia and the USA, besides facilitating foreign support provides regional leaders with justification for autocratic action.

Kazakhstan, due to its remoteness to the areas of tensions and the lack of extremist Islamic tradition and movements, is not as vulnerable as the other Central Asian states to the Islamist movement, but it also tries to 'benefit' from the threat. In contrast to Tajikistan and Uzbekistan, Kazakhstan was less concerned with and did not actively support the Northern Alliance in Afghanistan. Its peacekeeping troops in Tajikistan were under the jurisdiction of the CIS joint forces and never actively participated in serious combat or operations. T. Akimov asserted that Kazakhstan dealt only with the criminal and legal extension of the Afghan crisis and was interested in a stable and peaceful Afghanistan as an alternative route for its mineral resources to the open sea. ${ }^{29}$ The Kazakh government has expressed its apprehension about the growth of Islamic extremism on every occasion. Especially after the Russian involvement in Chechnya, it became a motto of Kazakh foreign policy. Kazakhstan's attitude towards Islamic extremism, separatism and terrorism keeps it in good terms with other Central Asian states, which have direct borders with other Islamic states and also leads Russia to tone down the protests against 'persecution' of Russians in Kazakhstan. Kazakhstan tries to present itself to Russia as a shield against drug-trafficking and Islamic extremism, and tells Russia that it should 'leave them on their own and do not interfere and they will do everything; only your interference and criticism obstruct their productivity'. ${ }^{30}$

The Kazakh government supported peaceful resolution of the Afghan war: the then Kazakh Foreign Minister Tokayev stated that Kazakhstan 'supports bringing an end to the war in Afghanistan and beginning talks on the resolution of the conflict' ${ }^{31}$ In contrast to Tajikistan and Uzbekistan, Kazakhstan preferred not to condemn the Taliban regime as the only reason for bloodshed and seemed even to refrain from recognizing the Rabbani government as the sole legitimate power representing Afghanistan. At the meeting of five Central Asian presidents held in Almaty on 28 February 1997, the Kazakh president did not make open accusations against the Kandahar regime, as the Uzbek and Tajik presidents did, and no special decision was taken. ${ }^{32}$ In May 2000, after Sergey Yastrzhembsky, the aide of President Putin, stated that Russia might use preventive air-strikes on Afghanistan, the Kazakh president said that there was no need for such air-strikes. ${ }^{33}$ After Yastrzhembsky's statement, the Taliban government warned Uzbekistan and Tajikistan that they would be held responsible for Russian attacks and threatened to use force against them. According to Erlan Karin, director of the Central Asian Agency of Political Research, it was not surprising that the Taliban threatened to use force in response to Uzbekistan and Tajikistan, 
because 'Tajikistan - no matter how we say - is a Russian colony and to some extent-Uzbekistan-under the circumstances of its peculiar relations with Russia ...'. ${ }^{34}$ In February 2000, a plane hijacked by Afghans was permitted to land at Aktöbe (Aktyubinsk) airport in Kazakhstan and was provided with food and fuel before taking off to London.

In fact, the Afghan war and the spread of extremism are still the most important excuse for the Kazakh government to increase its military power without annoying neighbouring states and to regulate the activity of domestic opposition. After 1999, particularly after the border incidents with Uzbekistan, Kazakhstan started to modernize and improve the combat ability of its armed forces. In May 1997, the then Kazakh Defence Minister, Mukhtar Altynbayev, stated that Kazakhstan plans in the future 'to transfer its army to work on a professional basis'. ${ }^{35}$ Following the border incident, Kazakhstan intended to increase its defence expenditures and provide extra tax privileges for arm producers. ${ }^{36}$ The Kazakh Defence Ministry ordered a number of the newest Russian military technologies, including several SU-27 and MIG-31 fighters and the S-300 air-defence missile system, which started being delivered in 1999. Because of military reforms and new weapon deliveries, Kazakhstan, with its army of only 68,000 personnel became the "most combat capable [country] in Central Asia'. ${ }^{37}$ In January 2000, Marat Tazhin, Security Council Secretary of the Republic of Kazakhstan, told that Kazakhstan planned to allocate at least 1 per cent of GDP to defence. The previous year's military spending of US $\$ 110$ million was equal only to 0.86 per cent of GDP. ${ }^{38}$ Beside military deliveries from Russia and privileges granted to domestic weapon producers, Kazakhstan has tried to gain support from external powers, especially NATO members. During the visit of the Kazakh Defence Minister Sat Tokpakbayev to the USA, the countries agreed to the joint manoeuvres of the Central Asian Battalion in Kazakhstan in September 2000. Another agreement was signed with the Turkish Defence Ministry in December 1999 and the Turkish side granted US\$600,000 non-refundable help for modernizing communication systems of the Defence Ministry of the Republic of Kazakhstan. ${ }^{39}$ During the infiltration of the Islamic militants in Southern Kyrgyzstan in September 1999, it was reported that the Kazakh Air Force bombed the militants' positions. However, the participation of the Kazakh forces was denied by the Kazakh Prime Minister Nurlan Balgymbayev, although he admitted that Kazakhstan provided some help to Kyrgyzstan with equipment and gear. ${ }^{40}$

Some of the above mentioned developments and changes have been compiled in a single document, the Military Doctrine of the Republic of Kazakhstan, which-approved by a presidential decree on 10 February 2000-renewed the former doctrine adopted two years previously. Certain issues that did not take place in the former doctrine have been confirmed in a new one. Interestingly, the doctrine says that 'the nearest surroundings of the country might be either potential allies or 'irritants' for the problem of security'; also 'the excessive quantitative and qualitative increase in the military power of some countries' are identified among the main threats to the country's security. ${ }^{41}$ 


\section{Kazakhstan and the Caspian Oil}

After the collapse of the Soviet Union, the Kazakh economy had considerably declined especially because of the drop in the production rate of oil and gas, the most important pillars of the Kazakh economy. In this regard, petroleum and gas production in the Caspian Sea region became probably the most important source for the state budget and supply of hard currency. Besides practical gains, the existence of rich oil and gas reserves improves the financial credibility of the state and attracts foreign investment. Between 1997 and 1999, US\$2.7 billion was directly invested in the oil and gas industry of Kazakhstan. ${ }^{42}$ Kazakhstan's rich oil reserves and the existence of several 'prospective' transportation routes grant it some political bargaining power, which the new republic is likely to utilize.

Unlike the rest of its foreign policy, the Caspian oil policy of Kazakhstan presents diverse perspective in international arena: the country seeks close relations with Russia and uses its pipelines as the only functioning export route for now; it encourages co-operation with Western petroleum companies to supply its oil to the world. Also there is the possibility of co-operation with regional states, such as Turkey, Iran and China. Commenting on diversity, Kazakh president said that 'here we are interested in a practical side of the matter, not political. Kazakhstan should start the transportation of its oil to the world market as soon and as profitably as possible. ${ }^{43}$ On 10 September 1999 , a protocol that confirms the will of two countries regarding the transportation of the Caspian oil via Turkey to the world market was signed in Ankara between Kazakhstan and Turkey. ${ }^{44}$

For Kazakhstan, it is crucial to delineate the dividing water lines in the Caspian Sea as soon as possible. Despite mention of a verbal consensus on the matter between the governments of Russia and Kazakhstan, ${ }^{45}$ Kazakhstan is anxious about the growth of Russian activity in the region, including its investment of US $\$ 9$ billion to develop the petroleum-producing infrastructure of its sector. ${ }^{46}$ Kazakhstan still claims its rights over the Khvalynskoye deposit in the border zone that was recently explored by Russian LUK-Oil. In early 2000, the State Customs Committee of the Russian Federation prohibited the transportation of Kazakh oil via Russian pipelines, arguing that the export of Kazakh oil via Russia could not be regarded as transit, because the oil that initially flows from Kazakhstan and that is exported at Russian ports (mixed with Russian oil) is not the same oil. ${ }^{47}$ This problem was solved during Nazarbayev's official visit to Moscow in June 2000, when the Russian Ministry of Energy stated that the transportation of Kazakh oil was in Russia's interests. ${ }^{48}$

\section{Sino-Kazakh relations: an alternative pole?}

Following the collapse of the Soviet regime and its economic ties and regional co-operation, Kazakhstan started to search for alternative relations with regional countries. The diversity of its relations would simultaneously underpin its 
sovereignty while also providing cheaper goods and exporting Kazakhstan's domestic production. Any possible alternative to the Russian economy would have lessened Kazakhstan's dependency on Russia and would contribute to the republic's independence. Under these circumstances, China started to dominate the region and had certain advantages that strengthened its position. First, China with its enormous population, export-import potential, and rapidly growing industry, provides a lucrative market for Kazakhstan's gas- and oil-dependent economy and is able to replace Russian imports with its cheaper basic consumer goods. Kazakhstan has a direct border with China so it might avoid Russia's political pressure and influence in exporting its own production, especially that of the oil sector. Second, China could certainly attract Kazakhstan with its 'economic miracle of achieving rapid modernisation without sacrificing political control' ${ }^{49}$ While Western powers, and sometimes even Russia, deal with the political and legal sides of development (such as lessening of state control over the economy, granting equal opportunities and developing means of political supervision), China has never urged Kazakhstan to install democratic institution s or to protect the rights of ethnic Russians in the republic. Another reason for the burst of trade and economic relations between the two countries, as Shireen Hunter pointed out, is the highly complementary natures of the two economies, whereas the instability in Afghanistan and sanctions over Iran makes China the 'shortest and cheapest outlet ... to the outside world'. ${ }^{50}$

According to Chinese customs statistics, Sino-Kazakh trade amounted to US\$390 million in 1995 (an increase of 17.7 per cent from 1994 trade), where the Kazakh exports amounted to US $\$ 324.5$ million (increasing by 47.5 per cent) and imports from China amounted to US\$65.5 million (a decrease of 37.5 per cent); in 1996 the volume of trade between the two countries reached US\$497.5 million. ${ }^{51}$ Trade and economic relations between China and Kazakhstan are likely to grow considerably and have already made China its greatest trading partner after Russia. Not surprisingly, the balance of trade is prone to change in China's favour. Economic ties between the two countries are also bolstered by co-operation in scientific, cultural and military fields, such as the Agreement on Scientific and Technological Co-operation signed on 30 December 1994, in Almaty $^{52}$ and an agreement on supplying the Chinese Navy with Kazakh-made torpedoes. ${ }^{53}$ For Kazakhstan, especially in recent years, Sino-Kazakh co-operation in the field of oil production and transportation via China has gained vital importance.

According to Viktor Gilinsky, world oil consumption will increase to 90 million barrels per day, in which Asian oil consumption will increase.$^{54}$ By the year 2005, Chinese demands for oil imports are expected to increase to 2 million barrels per day, or about 38 per cent of total consumption. ${ }^{55}$ As a result of China's growing need for oil, an important contract was signed by the Kazakh State Committee on Investments, the Aktyubmunaygaz Company of Kazakhstan and the Chinese National Petroleum Company (CNPC) on 26 September 1997. According to the contract, which will be valid for 20 years, CNPC will provide US $\$ 4$ billion in investments and during this period the Kazakh budget will 
receive US $\$ 3.16$ billion by means of income and local taxes, bonus and excise duties. ${ }^{56}$ Another agreement signed in Almaty in September 1997 stipulates the construction of a pipeline from Western Kazakhstan to Western China, which would become an alternative to the Caspian Pipeline Consortium established in 1992 to transport the Tengiz oil from Kazakhstan to the Russian Black Sea port of Novorossiisk ${ }^{57}$ At present, the transportation of Kazakh oil to China is provided mainly by railway. In 1998, the People's Republic of China (PRC) was to buy as much as one million tonnes of oil from Kazakhstan via railway and according to experts, might become Kazakhstan's major oil consumer. ${ }^{58}$ Then acting Prime Minister of Kazakhstan Ahmedzhan Esimov stated that a package of Kazakh-Chinese agreements on Caspian oil and its transportation was estimated at US\$9.5 billion. ${ }^{59}$ The possible transportation of Kazakh oil via China to Japan and other Southeast Asian countries is also being considered.

Kazakhstan, hampered by its disadvantageou s position of being a land-locked country and highly dependent on Russian transportation routes, considers the Chinese alternative as one of the most important and profitable solutions. Kazakhstan has direct rail, air and highway links with China and strives to develop their diversity and capacity. During a summer 1991 visit to China, president Nazarbayev offered to extend the current Almaty-Urumchi and Beijing air routes and use it as a transit base from Kazakhstan to Japan and South Korea. Also he offered to increase the volume of transportation of the railroad line between China and Russia via Kazakhstan. Another agreement signed during the September 1995 visit of Nazarbayev to China dealt with Kazakhstan's trade exchanges with Pacific and Southeast Asian countries to be conducted via the Chinese port of Lianyungang saving some $5000 \mathrm{~km}$ in transport-the distance from Kazakhstan to this port is $3500 \mathrm{~km}$, while that to the nearest Russian Far Eastern port is $8500 \mathrm{~km}^{60}$

\section{Eastern Turkestan and Kazakhstan's policy}

The Xinjiang Uygur Autonomous Province (XUAP), or Eastern Turkestan, has a great strategic, economic and political importance for Sino-Kazakh relations. Recognition of Chinese supremacy over the region and 'non-intervention' in domestic affairs has been a long-standing condition for Kazakhstan's relations with China. Kazakhstan has certain historical linkages with Eastern Turkestan, which was formally incorporated into the Chinese Empire in 1884. In 1933 and again in 1944, an independent Eastern Turkestan Republic composed mainly of Uighurs and Kazakhs was established. ${ }^{61}$ According to the Chinese statistics, some 1,111,718 ethnic Kazakhs live in Eastern Turkestan ${ }^{62}$ (Kazakhs claim that there are at least 1,500,000) and a considerable number of ethnic Uighurs (the largest ethnic group in Eastern Turkestan many of whom fled to Kazakhstan in the 1930 s through to the early 1960s $)^{63}$ live in Kazakhstan. The Muslim population of China, which is severely suppressed by the Chinese government, suffered from a policy of assimilation and planned immigration of the Chinese into the region. As a result, the Muslim population has become opposed to the 
regime, making the People's Republic of China (PRC) government anxious, especially after the collapse of the Soviet Union and the growth of ethnic and religious awareness throughout Central Asia. According to controversial official Chinese figures, among the Province's total population of 15.2 million, the Uighurs represent the largest ethnic community with 7.19 million (47.5 per cent), the Kazakhs 7.3 per cent, the ethnic Chinese Muslims number 782,000 (4.5 per cent) and some other ethnic groups such as Kyrgyz and Mongols number 140,000 (0.8 per cent) each. ${ }^{64}$ While 60.1 per cent of the region's entire population consist of Muslims, the number of Chinese has risen to 5.7 million (37.6 per cent). ${ }^{65}$ The ethnic Kazakh minority in Eastern Turkestan represents the largest Kazakh community among 4.5 million Kazakhs living outside Kazakhstan. In contrast to the People's Republic of China's other regions, Eastern Turkestan is still largely controlled by the People's Liberation Army (PLA), not the Armed Police and the province still suffers from the nuclear weapons testing centre at Lob Nor, which also places a great number of military staff in the region. ${ }^{66}$

With the establishment of diplomatic relations with the People's Republic China the Kazakh government recognized that,

[T] he government of the People's Republic of China is the only legitimate government of China and Taiwan is an indivisible part of the Chinese territory. The Government of the Republic of Kazakhstan guarantees, that it would not establish any kind of official relations with Taiwan. ${ }^{67}$

Although, there is no such direct official statement on the non-involvement of Kazakhstan in Eastern Turkestan, the Kazakh government guarantees this under the guise of the struggle against separatism, terrorism and ethnic strife. In order to satisfy its southern neighbour and preventing it from demanding security guarantees, the Kazakh government not only refrains from displaying concern for its fellow Kazakhs or other kin communities in Eastern Turkestan and their problems, but also commits itself 'to prevent advocates of an 'East[ern] Turkestan Republic' from working against China and interfering in Xinjiang from the territory of Kazakhstan' ${ }^{68}$ In July 1996, the two countries signed a 'treaty on mutual extradition of criminals and criminal suspects'. ${ }^{69}$ Following several occasions of extradition of ethnic Uighurs who had fled to Kazakhstan, the republic was regarded as having 'collaborated with Chinese authorities and violated international treaties by peremptorily returning to China those ethnic Uighurs from China who had fled to Kazakhstan and claimed political refugee status by reason of racial persecution'. ${ }^{70}$

In addition to the province's strategic and demographic importance, Eastern Turkestan plays a key economic role for China, Kazakhstan and the entire Central Asian region. The Treaty of Principles and Main Trends of the Promotion of Co-operation between the province and the then Kazakh SSR was signed during President Nazarbayev's visit to XUAP. ${ }^{71}$ In 1991, the total volume of trade between the Central Asian republics and the Province amounted to US $\$ 1$ billion and in 1992 it reached US $\$ 2$ billion. ${ }^{72}$ Following this, the Chinese 
government granted five cities in the province the same rights as the ten 'open cities' on the East coast. ${ }^{73}$ The growing relations with Kazakhstan also spurred the economic development of Eastern Turkestan, in which more than 70 per cent of the region's external economic exchanges were conducted with Central Asian countries, ${ }^{74}$ attracting investments to the region and improving its welfare.

\section{The Shanghai forum}

The Shanghai Agreement on Confidence-building in the Military Field in Border Areas, which created the 'Shanghai Five', was signed on 26 April 1996, between the People's Republic of China and four former Soviet neighbouring states: Kazakhstan, Kyrgyzstan, Tajikistan and Russia. The agreement stipulates the mutual dislocation of military troops and armament, except border troops, from a border zone of $100 \mathrm{~km}$; the parties agree to refrain from allowing military manoeuvres to target another side and limit the scale of manoeuvres and the number of staff attending them. ${ }^{75}$ Also, signatories to the treaty would be able to observe military exercises in order to prevent any dangerous military activities. $^{76}$

The Republic of Kazakhstan actively participated in the Shanghai Five meetings. This was to its advantage: first, it was a forum where the republic could contact and observe its two great neighbours; second, the implementation of the agreement could free it from the heavy burden of armament and avoid unfavourable tension; and last, the Shanghai Five was more than just a military or border agreement providing certain economic co-operation opportunities. Initially, Russia sponsored talks with China and Kazakhstan, Kyrgyzstan and Tajikistan on their common border issues and the limitation of troops and weapons. In April 1995, negotiation s were held in Moscow between the working groups of the countries. ${ }^{77}$

At the summit meeting of the Shanghai Five leaders held in Bishkek, on 25 August 1999, the participants signed a declaration in which the members expressed their resoluteness "not to permit the use of the territories of their countries for the organization of activities violating the sovereignty, security, and public order of any of the five states. ${ }^{78}$ Besides lending support for the creation of a nuclear-free zone in Central Asia, the participants unofficially condemned separatism and 'Islamic fundamentalism' ${ }^{79}$

The meeting of the Shanghai Five held in July 2000 in Dushanbe, was distinguishe $d$ from the previous meetings in several ways. The Dushanbe summit was the first meeting of the Shanghai Five series attended by the new Russian President Vladimir Putin whose neo-imperialist policies forced him to keep close to his eastern neighbours. In February 2000, Putin, then acting president and Prime Minister, appointed Vladimir Vorobyev as the special envoy to the Shanghai Five. ${ }^{80}$ The Shanghai Five summit had great importance for the new Russian leader and probably was the only forum where he could get official support for his 'anti-separatist' and 'anti-terrorist' operations in Chechnya. Interestingly, Kazakhstan was the only country that did not face any threat of 
'Islamic extremism' whatsoever. Its greatest threat is Russian separatism in the north and the border dispute with China. The Dushanbe summit was attended by the Uzbek President Islam Karimov, who did not attend the previous meetings. The leader of Uzbekistan, whose country does not have common borders with Russia and China, is deeply concerned with the struggle against his opposition that has been alleged to co-operate with Islamic militants.

Before the summit started, the foreign ministers of the member states signed a communiqué on the joint struggle against terrorism, even committing themselves to large-scale anti-terrorist operations. Additionally, the sides decided to co-operate in the economic and cultural spheres. ${ }^{81}$ The leaders of member states again expressed their opposition to interference in the interior affairs of other states even 'under the excuse of humanitarian intervention and protection of human rights'. ${ }^{82}$ Besides Uzbekistan, some other regional states, namely Mongolia, India and Iran, expressed their interest in co-operation with the Shanghai Five, henceforth being called 'Shanghai Forum'. ${ }^{83}$

\section{The border issue and Chinese expansionism}

The issue of the $1700-\mathrm{km}^{84}$ long Sino-Kazakh border, a legacy of the Russian imperial regime, was settled by the St Petersburg Treaty of 1881 and its further provisions of 1883, 1904 and $1915 .{ }^{85}$ This border is one of the most vulnerable chains in Kazakh national security. Throughout history, China expressed its imperial mood to expand in Central Asia through incorporation of lands and assimilation of native population. In the past, and especially during Mao's rule, China laid certain claims on Kazakh border territories and intended to change the border, namely in 1968 and 1971. In 1992, after Kazakhstan became an independent state, the Chinese ambassador to Kazakhstan argued that the Kazakh-Chinese border needed correction. ${ }^{86}$ It was said that the Chinese term $X i$ $Y u$, meaning 'Northwest province' in Chinese is an 'historical designation for an area encompassing much of Central Asia' ${ }^{87}$ The Chinese territorial claims are underpinned by the great involvement of China in Kazakh economy, immigration and the settlement of Chinese in Kazakhstan. While in the 1989 census no Chinese were counted, it is estimated that some 300,000-350,000 Chinese live in the republic today. ${ }^{88}$ Also, it is well known that the Chinese armed forces located in the region are superior in armament and number to the armed forces of Russia and the CIS countries located in Central Asia. ${ }^{89}$ Also the Chinese nuclear testing centre situated at Lob Nor, is only $900 \mathrm{~km}$ from the Kazakh border and only $1200 \mathrm{~km}$ from Almaty. From 1964 to 1992, 38 nuclear bombs were tested there and those before 1980 were exploded in the air, causing harmful radiation for the whole region. ${ }^{90}$ This actual Chinese threat prevents Kazakhstan and other Central Asian states from distancing itself too much from the Russian Army. It remains the only power to rely on in case of Chinese invasion, despite the Chinese promise given to Kazakhstan on 8 February 1995, that 'it would never use nuclear weapons against it' ${ }^{91}$

One of the most sensitive issues in Sino-Soviet relations, the border issue 
between China and Kazakhstan, was addressed by signing an 'historic' border accord on 26 April 1994-exactly two years before of the signing of the Shanghai Agreement-during the visit of the Chinese Prime Minister Li Peng to Kazakhstan. ${ }^{92}$ Negotiations on defining today's Sino-Kazakh border began in the 1970s and 'were near completion when the Soviet Union collapsed in 1991', leaving a stretch of $73 \mathrm{~km}$ undefined. ${ }^{93}$ Following the agreement, the joint Kazakh-Chinese commission on the border demarcation was established, and in 1996 and July 1998, the two sides signed two complementary agreements on border issues, during the visits of the Chinese President Jiang Zemin to Kazakhstan. ${ }^{94}$ During the negotiations, the Chinese side pressed its claims over a 364-square-mile area of disputed territories and launched a project of diverting up to 40 per cent of border rivers to China. Under pressure Kazakhstan agreed to cede 157 square-miles to China. ${ }^{95}$

The Kazakh Government tried to derive benefit from the Shanghai Five meetings at every possible stage, including during tête-à-tête meetings between the Kazakh and Chinese presidents. During the Bishkek Round of the Shanghai Five, the two presidents 'completely solved all border problems between the two countries'. ${ }^{96}$ During the later summit of the Shanghai Forum, President Nazarbayev also stated that the border problems were actually solved. ${ }^{97}$ In June 2000, other negotiation s on the issue of border rivers were held in China, after which the Chinese side decided 'to take Kazakhstani interests into account when outlining all the projects on construction of any objects on and/or along the rivers crossing the borders of the two countries'. ${ }^{98}$

\section{Conclusion}

Today, Kazakhstan-as any of the Central Asian ex-Soviet states-is busy solving its domestic and economic problems. This facet of their interests and policy makes the present-day intra-Central Asian relations considerably different from the early years of independence, when despite their economic and political controversies their co-ordinated policy and attitude was the key to their survival vis-à-vis Russia. Despite its few years of independence and severe political and economic dependence on its neighbours, Kazakhstan seems today able to afford a more pragmatic policy in economic and strategic terms. The decree on the visa regime for the Kyrgyzstani citizens is itself an evidence of remarkable changes.

The analysis of Kazakhstan's regional policy since its 'catapult to independence', especially that of the last few years, shows that two major trends will dominate its future regional policy: the establishment of interactions with the neighbouring countries favourable in economic terms and the entrenchment of balanced (or counterbalanced) relations with Russia and China.

Ironically, the complexity of regional interests encourages the development and expansion of multilateral institutions and unions in the region but impedes their functioning and imposition, providing countries like Kazakhstan with de jure umbrella but without any serious controlling body. Kazakhstan seems fully aware of this. Indeed, this was true for the Commonwealth of Independent 
States, where Kazakhstan was one of the most active participants and the initiator of a number of forums, projects and treaties. Today, a similar trend seems valid for the Shanghai Union, which expands its 'jurisdiction' over more and more members and problems and where Kazakhstan plays a similar active and 'expansionist' role. In this respect, the declaration of Nursultan Nazarbayev that the Shanghai Union should also deal with ecological and humanitarian issues apart from its political and economic questions and should strengthen its co-operation with other international and regional organizations, such as ASEAN, ${ }^{99}$ is worthy of being scrutinized.

\section{Notes and references}

1. Mirza Haydar Dughlat, 'Tarikh-i-Rashidi: a history of the Hans of Moghulistan', Sources of Oriental Languages and Literatures, No 38 (Massachussetts, 1996), p 154; cited by Meryem Kirimli, 'The genesis of Kazakh nationalism and independent Kazakhstan: a history of native reactions to Russian-Soviet policies', unpublished Doctoral Dissertation, Bilkent University, Ankara, 1999, p 26.

2. U.S. Central Intelligence Agency 1995; and International Institute of Strategic Studies 1995; both cited by Philip G. Roeder, 'From hierarchy to hegemony: the post-Soviet security complex', in David A. Lake and Patrick M. Morgan (eds), Regional Orders: Building Security in a New World (University Park, PA, 1997), p 231.

3. Dmitry Trofimov, 'Regional preeminence in Central Asia', Priism-A Monthly on the Post-Soviet States, Vol 6, No 2, Part 4 (February 2000).

4. Shireen Hunter, Central Asia Since Independence (Westport, CT, 1996), p 93.

5. Kazakhstanskaya pravda (25 June 1990); cited by Martha Brill Olcott, Central Asia's New States: Independence, Foreign Policy and Regional Security (Washington, D.C., 1996), p 52.

6. Hunter, op cit, Ref 3, p 108 .

7. Vyacheslav Belokrenitsky, 'Russia and former Soviet Central Asia: the attitude towards regional integrity', in Touraj Atabaki and John O'Kane (eds), Post-Soviet Central Asia (London, 1998), p 51; and Olcott, op cit, Ref 5, p 55.

8. Ibid.

9. 'Nazarbaye v ratifies agreement with Uzbekistan', FBIS-SOV-94-050 (5 March 1994); cited by Hunter, op cit, Ref 4, pp 102-103.

10. Kasymzhomart Tokayev, Pod styagom nezavisimosti: Ocherki o vneshney politike Kazakhstana (Almaty, 1997), p 95.

11. Ibid.

12. 'Nazarbayev: Eurasian Union meets CIS interests', Interfax, 16:36 GMT (20 Sep 1994); in FBIS-SOV-94183.

13. Tokayev, op cit, Ref 10, p 105.

14. S. Kozlov, 'Astana obvinyayet Tashkent v ekspansii', Nezavisimaya gazeta, No 18 (2080), (2 February 2000).

15. 'Na yuge Kazakhstan a aktivizirovalis' uzbekskiye spetssluzhby', Tsentral 'noaziatskiy byulleten' (9 February 2000).

16. 'Border trouble', Economist (19 February 2000), Vol 354, No 8158, pp 43-44.

17. Kozlov, op cit, Ref 14.

18. Ibid.

19. Paul Goble, 'Kazakhstan: analysis from Washington-“Good fences make good neighbors", Türkistan Newsletter (An on-line newsletter and Discussion List on Turkic Peoples) (27 April 2000).

20. 'Kazakhstan begins planned Uzbek border troop location', Interfax, 12:24 GMT, 7 September 1999; in FBIS-SOV-1999-0907.

21. 'Uzbekistan strengthens boundary guard, but no territorial claims', Türkistan Newsletter (9 March 2000).

22. Panorama (Almaty), No 22 (2 June 2000).

23. Panorama (Almaty), No 27 (9 July 2000).

24. Kozlov, op cit, Ref 14.

25. Ibid.

26. Trofimov, op cit, Ref 3.

27. Ibid. 
28. Anthony Hyman, 'Power and politics in Central Asia's new republics', in Mark Beloff (ed), Beyond the Soviet Union: The Fragmentation of Power (Aldershot, 1997), p 202.

29. T. Akimov, 'Afganistan: de jure i de facto: Komu vygoden ognennyi Afganistan?', IA Kabar (Kyrgyzstan) (12 June 2000).

30. Strany Tsentral'noy Azii vnov' dobrovol'no vstupyat v sostav Rossii?', Radio Liberty (26 May 2000); in IAC Eurasia, www.eurasia.org.ru.

31. 'Kazakhstan: Kazakhstan Says Afghan conflict threatens Central Asia', Interfax, 14:51 GMT, 24 December 1998; in FBIS-SOV-98-358.

32. 'Kazakhstan: Central Asian presidents concerned on Afghanistan events', Interfax, 21:37 GMT, 28 February 1997; in FBIS-SOV-97-041.

33. 'Nikakiye antitalibanskiye udary ne nuzhny—Nazarbayev', Vremya Po Grinvichu (30 May 2000).

34. 'Strany Tsentral'noy azii', op cit, Ref 30.

35. 'Kazakhstan: Defence Minister: Kazakhstan aims for professional army', Interfax, 13:24 GMT, 9 May 1997; in FBIS-UMA-97-129.

36. 'Na yuge Kazakhstana', op cit, Ref 15.

37. 'Kazakhstan: Kazakhstan to receive Russian combat aircraft missiles', ITAR-TASS, 18:20 GMT, 1 February 1999; in FBIS-TAC-1999-032.

38. 'Kazakh mull more defense money to counter threats', Reuters (20 January 2000).

39. Vladimir Georgiyev, 'Rossiya i NATO obustraivayut Kazakhstanskuy u armiyu', Nezavisimaya gazeta, No 243 (2059) (28 December 1999).

40. 'Kazakh premier denies bombing Islamic militants', Interfax, 17:40 GMT, 23 September 1999; in FBIS-SOV-1999-0923.

41. 'Voyennay a doktrina Kazakhstana: armiya poluchit garantirovannoe finansirovaniye', Panorama (Almaty), No 7 (February 2000).

42. 'Nursultan Nazarbayev: My za mnogopolyusny i mir', Nezavisimaya gazeta (24 February 2000).

43. Ibid.

44. 'Protocol signed with Kazakhstan supports Baku-Ceyhan line', Ankara Anatolia, 19:51 GMT, 10 September 1999; in FBIS-WEU-1999-0911.

45. Dmitriy Kozhukhin, 'Kaspiyskoye more podelyat v etom godu', Express-K (24 May 2000).

46. Ibid.

47. Viktor Shelgunov, 'Nazarbayev idyet v bank', Tsentral'noaziatskiy byulleten' (IAC Eurasia) (16 June 2000).

48. 'I eto vsye-pro neft", Vremya novostey (IAC Eurasia) (21 June 2000).

49. Olcott, op cit, Ref 5, p 35.

50. Hunter, op cit, Ref 3, pp 128-129.

51. Tokayev, op cit, Ref 10, pp 225-226.

52. 'PRC-Kazakhstan sign agreement on technological ties', Xinhua, 20:47 GMT, 30 December 1994; in FBIS-CHI-95-002.

53. 'Kazakhstan: Kazakhstan to supply torpedoes to Chinese navy', ITAR-TASS, 10:21 GMT, 19 June 1998; in FBIS-SOV-98-170.

54. Viktor Gilinsky, 'Energy in the former Soviet Republics', in David Carlton and Paul Ingram (eds), The Search for Stability in Russia and the Former Soviet Bloc (Aldershot, 1997), p 62.

55. Oil and Gas Journal (28 August 1995); cited by John Calabrese, 'Çin'in Orta Asya'daki politikas 1 Yenileme ve Üslenme', Avrasya Etüdleri (Ankara), No 16 (Autumn-Winter 1999), p 88.

56. 'Kazakhstan: Almaty, Beijing sign Kazakhstan oil exploration accord', Interfax, 09:24 GMT, 26 September 1997; in FBIS-SOV-97-269.

57. 'Kazakhstan: Kazakhstan-China agreement include pipeline project', Interfax, 15:59 GMT, 25 September 1997; in FBIS-SOV-97-268.

58. 'Kazakhstan: China to buy 1 million tonnes of Kazakh oil this year', ITAR-TASS, 10:50 GMT, 17 April 1998; in FBIS-SOV-98-108.

59. 'Kazakhstan: Kazakhstan-China agreement include pipeline project', op cit, Ref 57.

60. 'PRC: "Roundup" views Sino-Kazakhstan relations', Xinhua, 02:58 GMT, 3 June 1996; in FBIS-CHI-96130.

61. Peter Ferdinand, 'The new Central Asia and China', in Peter Ferdinand (ed), The New Central Asia and Its Neighbours (London, 1994), p 96.

62. 'State Statistical Bureau', Beijing Review No 52 (1990), p 30; cited by Hafeez Malik, 'New relationship between Central and Southeastern Asia and Pakistan's regional politics', in Malik Hafeez (ed), Central Asia: Its Strategic Importance and Future Prospects (New York, 1994), p 255.

63. Robert M. Cutler, 'Kazakhstan's ethnic mix: recipe for a shatterbelt in Central Eurasia', Türkistan Newsletter (13 December 1999). 
64. Thomas Hoppe, 'Die chinesische Position in Ost-Turkestan/Xinjiang', China Aktuell (June 1992), p 360; cited by Ferdinand, op cit, Ref 61, p 98.

65. Ibid.

66. Ferdinand, op cit, Ref 61, p 98.

67. Tokayev, op cit, Ref 10, p 193.

68. China Aktuell (April 1994), p 392; cited by Ferdinand, op cit, Ref 61, p 100.

69. 'Kazakhstan: Nazarbayev, Jiang Zemin Sign Joint Declaration', Interfax, 07:36 GMT, 5 July 1996; in FBIS-SOV-96-130.

70. Cutler, op cit, Ref 63.

71. Tokayev, op cit, Ref 10, p 192.

72. Ferdinand, op cit, Ref 61, p 102.

73. Ibid.

74. 'Xinjiang increasing ties with Central Asian republics', Xinhua, 03:36 GMT, 3 March 1995; in FBIS-CHI-95-042.

75. L.K. Bakayev and N.O. Urpekov, Voyennaya i vneshnyaya bezopasnost' Kazakhstana na poroge XXI veka (Almaty, 1998), p 41.

76. 'PRC: 5-nation military agreement signed in Shanghai', Xinhua, 09:41 GMT, 26 April 1996; in FBIS-CHI-96-082.

77. 'China, 4 CIS member states hold border talks', Xinhua, 16:07 GMT, 10 April 1995; in FBIS-CHI-95070.

78. Panorama (Almaty), No 33 (27 August 1999).

79. Ibid.

80. 'Putin appoints special envoy to "Shanghai Five", ITAR-TASS; in FBIS-CHI-2000-0217.

81. Panorama (Almaty), No 27 (9 June 2000).

82. Ibid.

83. Ibid.

84. Tatiana Shaumian, 'Foreign policy perspectives of the Central Asian states', in Atabaki and O'Kane, op cit, Ref 7, p 70.

85. Murat Laumulin, Foreign Policy and Security of the Republic of Kazakhstan (Almaty, 1997), p 77.

86. Express, 20 November 2000; and Aziya no 1993; both cited by Laumulin, op cit, Ref 85, p 77.

87. Steven Shabad, 'Chinese inroads: Central Asia', World Press Review, Vol 46, No 9 (September 1999), $\mathrm{p} 24$.

88. Ferdinand, op cit, Ref $61, \mathrm{p} 103$.

89. Laumulin, op cit, Ref 85, p 79.

90. Shaumian, op cit, Ref 84, p 70; Laumulin, op cit, Ref 85, p 80.

91. 'China gives security assurance', B-Wire, B-WIRE/FF00480, 13: 04:44.

92. "China, Kazakhstan sign "historic" border accord', B-WIRE/FF0103, 14:56:59.

93. Nadira Artykova, 'Kazakhstan and Chinese settle border dispute', B-WIRE/FF06533, 12:11.23 (26 April 1994).

94. 'China: China, Kazakhstan sign border agreement', Xinhua, $07: 17$ GMT, 04 July 1998; in FBIS-CHI-98185.

95. Shabad, op cit, Ref 87.

96. Panorama (Almaty), No 33 (27 August 1999).

97. Panorama (Almaty), No 09 (June 2000).

98. Kazakh News (Electronic RL/RFE News Bulletin) (June 27 2000).

99. 'Jiang men Putin bilek biriktirude', Egemen Kazakstan (19 June 2001). 